\title{
粉体の動特性と粒子特性*
}

荒 川 正 文**

\section{Dynamic Properties of Powder and Particle Characteristics}

\author{
by
}

\author{
Masafumi ARAKAWA
}

(Institute for Chemical Research, Kyoto University, Uji)

\section{1 まえがき}

粉体の取り扱いにおいてその動的な挙動が問題にな る場合はきわめて多い。ここで動的というのは，その 粉体系中に含をれる全粒子または局所的な粒子群に掠 いて粒子相互の位置関係化変化が和こるといら意味で あり，これに起因する粉体の性質を動特性，このよう な動的挙動による現象を広い意味での流動現象という こととする.

粉体の流動現象は，とくに工学的な操作ではそのほ とんどに関係している.三輪は粒子が運動するための エネルギの与方によって重力流動, 機械的強制流動, 振動流動，圧縮流動，流体に伴われた流動といらょう に分類しているが，実際にはこれらが複雑に重なった 場合が渒とんどであろう。しかし，粉体系中に含まれ る粒子の挙動との関連を考兄てこれらの流動機構を知 ることは容易でない，たとえば流動層に和ける粉体の 動特性や回転円筒内户移動層内の粉体中の粒子の拡散, オリフィスやホッパからの排出過程などについて流動 現象を解析した例は多数あるが，それらの結果を，た と兊ば液体の粘度の上らな特性值として一般的治掁 できないのは，それぞれの操作に和ける粉体の動構造 や粒子間相互作用を明確に規定できないことによると 思われる．流動現象がいかなる機構にもとづくもので あっても，個々の粒子が集合系の中で相互の位置関係 を变えるという現象に関与する最も基礎的な因子は粒 子自身の運動エネルギ，粒子間の摩擦や機械的なから 久合いなども含めた広義の粒子間相互作用力——ポテ ンシァルェネルギ，拉よび粒子が移動できる空げきの 存在状態一一充てん構造である. 粒子の運動エネルギ はその質量，すなわち粒度と関係づけられるが，動的 状態に括沙る粒子の充てん構造や粒子間相互作用力を

* 原稿受理 昭年49年 3 月 8 日

** 正 会 員 京都大学化学研究所 宇治市五ヶ庄
知ることはかなり困難である。

粉体の動特性の基礎的な研究を执こなうにあたって

Table I. Characteristics of sample powder.

\begin{tabular}{|c|c|c|c|c|}
\hline Materıals & Code & Density & \begin{tabular}{|l|} 
Particle \\
size $(\mu)$
\end{tabular} & Remarks \\
\hline \multirow{6}{*}{$\alpha$-Alumına } & WA-100 & 391 & 120 & \\
\hline & WA-400 & " & 40 & \\
\hline & WA-800 & $"$ & 20 & \\
\hline & WA-1000 & $"$ & 16 & \\
\hline & WA-1500 & $"$ & 12 & \\
\hline & WA-2500 & $"$ & 6 & \\
\hline \multirow{7}{*}{ Calcite } & $\mathrm{CaCO}_{3}-\mathrm{SZ}$ & 2.70 & 15 & \\
\hline & $\mathrm{CaCO}_{3}-\mathrm{SZP}$ & $"$ & 15 & Fatty acid coat \\
\hline & $\mathrm{CaCO}_{3}-5$ & $"$ & 5 & \\
\hline & $\mathrm{CaCO}_{3}-8$ & $"$ & 8 & \\
\hline & $\mathrm{CaCO}_{3}-20$ & $"$ & 20 & \\
\hline & $\mathrm{CaCO}_{3}-100$ & $"$ & 90 & \\
\hline & $\mathrm{CaCO}_{3}-100 \cdot \mathrm{C}$ & $"$ & 90 & Fatty acid coat \\
\hline \multirow{12}{*}{ Glass beads } & GB-706 & 2.52 & 320 & \\
\hline & GB-705 & " & 230 & \\
\hline & GB-733 & $"$ & 100 & \\
\hline & GB-733-S1 & " & 100 & Silicon coat. \\
\hline & GB-733-110 & " & 110 & \\
\hline & GB-733-80 & " & 80 & \\
\hline & GB-3M-550 & $"$ & 37 & \\
\hline & GB-3M & 2.43 & 12 & \\
\hline & GB-3M-Si & $"$ & 12 & S1licon coat \\
\hline & GB-ST & 655 & 46 & \\
\hline & $\mathrm{GB}-\mathrm{ST}-\mathrm{S} 1$ & " & 46 & Silicon coat. \\
\hline & GB-ST-Ag & $"$ & 46 & Silicon coat. \\
\hline \multirow{7}{*}{ Glaphite } & $\mathrm{Gr}-90$ & 223 & 90 & \\
\hline & $\mathrm{Gr}-130$ & 2.22 & 130 & \\
\hline & $\mathrm{Gr}-180$ & 204 & 180 & \\
\hline & Gr-230 & 2.06 & 230 & \\
\hline & $\mathrm{Gr}-280$ & 207 & 280 & \\
\hline & Gr-450 & 212 & 450 & \\
\hline & $\mathrm{Gr}-\mathrm{S}$ & 1.42 & 49 & \\
\hline Bronze sphere & Bronze & 880 & 230 & \\
\hline Potato starch & STARCH & 15 & 40 & \\
\hline Nylon-66 & Nikolon & 12 & 30 & \\
\hline
\end{tabular}


の問題点は，まず，同一試料で動構造を系統的に変え ることと, そのときの粒子群の充てん構造に関する情 報を得ることである. 系統的に動構造を変えるために は，たとえば流動層や振動粉体層を利用できるし，ま た適当な容積分率（空げき率と考学ることができる） で溶媒中に粉体を分散させた固一液系の挙動を固一気系 にあてはめることも問題によっては可能である。しか し，流動層はかなり大きな粒状試料では成功した例が あるが，一般の粉体ではバブルの発生などのために系 全体の動構造を均一に変化させることは難しく，また 固-液系からの類推も粒子間の相互作用機構が乾燥粉 体のそれと異なるので同一の議論の対称とならないの が普通である (考え方のモデルにはなる). これらに 対して, 振動粉体層は容器形状や振動方法など問題点 は多いが条件の選定は比較的容易であり利用しやすい， 著者らはこれまで振動粉体層を用いて振動強度と粉体 の流動性, 振動粉体層の動構造, 動特性之粒子特性, 流動粉体中での粒子特性にもとづく分離，偏析などに ついて幾つかの実験を試みてきた。これらの結果をま とめてここに述べることにする.

なお，これらの実験に用いた試料粉体をまとめて Table I に揭げておく.

\section{2 容器からの粉体排出速度と振動粉体の流動性}

粉体の流動性試験の方法の一つに容器からの排出速 度の測定があり，粉体の種類によって各部の寸法が多 少異なったホッパやオリフィスが使用されている。こ のような方法による粉体の排出速度と粒子特性, とく に粒度との関係を二，三の粉体について検討した，実 験装置はFig. 1 のおりで，バイブレータに取り付け たガラスロートのロ径 $d$ を変え, 粒度の異なる黒鉛粉 体の重量排出速度 $W$ との関係を測定した. 結果をW と $d / D_{p}$ の関係で示すと Fig. 2のようになる.ここで $D_{p}$ は粒度である。同じ粒度の場合は $d$ が大きくなる と排出速度が増加し，よく知られている(1)式の関係が 成立する。

$$
W=K \cdot d^{n}
$$

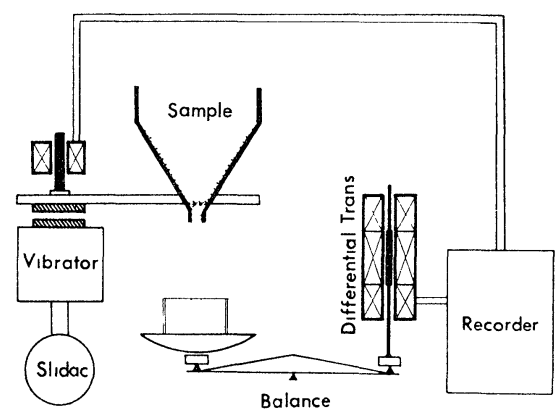

Fig. 1. Schematic diagram of the apparatus for measurement of flow rate of powder.

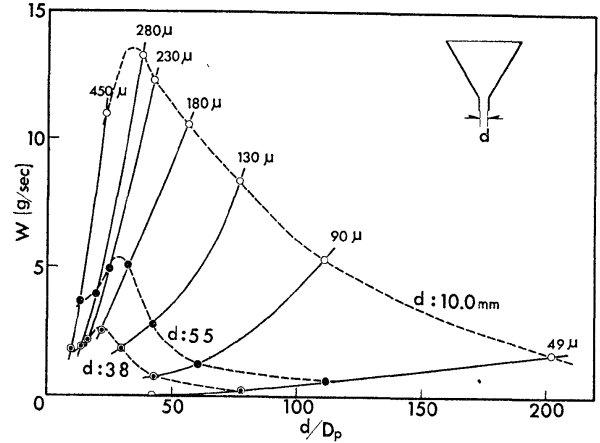

Fig. 2. Effect of orifice diameter and particle size on flow rate of graphite powder.

しかし，同じ口径 $d$ にいては粒度 $D_{p}$ によって排 出速度が異なり, Pilpe1 らによって指摘されているよ らに速度の最大值が存在する。.Fig. 1 のロートをオリ フィスに変えて同じくWと $d$ の関係をしらべた結果も 同じ傾向を示し，これはガラス球，石灰石粉砕物など についても認められる. Pilpel はさらに粉体層のせん 断試験により求めた内部摩擦係数や，かく汼に要する トルクについても同じく粒度に対して極小点が存在す ることを認め，他にも同様の報告がある．本実験の試 料についても注入法による安息角と粒度の関係にやは り極小值が認められた。

この現象に対しては, 微粒子側では粒子の付着・凝 集性, 粗粒子側では架橋現象による閉塞のために排出 速度が減少し，その間に速度最大になる粒度条件があ るという説明がなされている。ささて, 粒子の架橋は容 器に適当な振動を与えると崩壊して流出は容易になる であろらし，また粒子の付着・凝集も振動によって影 響されるであろら。そこで，ロートに $60 \mathrm{~Hz}$ の振動を 加光, 振幅を変えて排出速度に対する効果をしらべた。

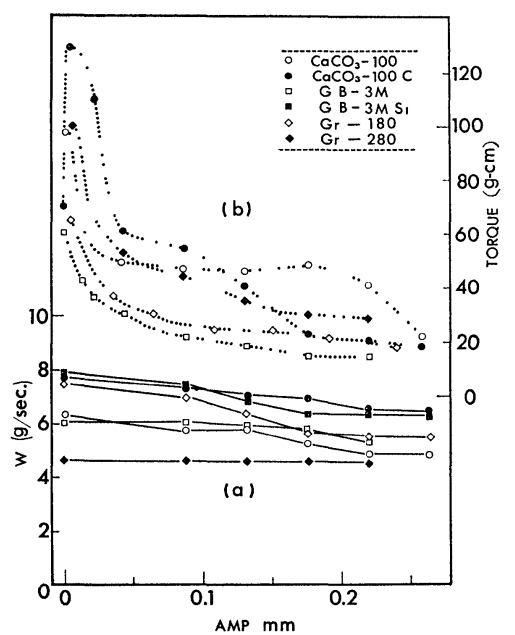

Fig. 3. Effect of vibration on flow rate and fluidity of various powder. 
その結果はFig. 3(a)のように排出速度は振動によりむ しろ低下す尚傾向がある。 しかし，後述のFig. 4 亿示 したような装置で測定した粉体層のかく找トルクは Fig. 3(b)のように振幅の增加につれて最初は急激に, その後は徐々にトルクが減少し粉体層の流動性が静止 時の数倍になることがわかる.

また，Fig. 3 と执いて $\mathrm{CaCO}_{3}$ ， GB などの排出速度 は表面処理により粒子を䠅水性にした方が大きく，見 掛けの流動性は増しているのに，かく捧トルクはむし ろ增加している。 この相違については以下のように考 兄られる. 容器からの排出は重力による粒子の自由落 下現象であり，それに伴って粒子の移動する空間が容 器下部から上部につぎつぎと伝わり，排出速度をきめ るのはオリフィス上部のいわゆる動的アーチに执ける 粒子の衝突, 粒子間の摩擦のような相互作用力が支配 的であろう．したがって系全体の空げき率を変えるよ らな振動の効果は比較的小さく, むしろ粒子の衝突回 数が增加するなどの理由で排出速度が低下することが おこる，また，粒子の表面処理による疎水化は表面の 水膜形成を妨げるために粒子間相互作用力が減少し排 出速度が増加する。一方, 安定な状態に充てんされ, 空げきの少ない静止状態では, 試料の見掛け体積を増 加させ粒子の移動できる空間を形成するために大きな かく拌トルクが必要であるが，振動によって外部から 別にエネルギを加えると個々の粒子の運動量が增しか く找トルクは低下する。したがって振動の効果は影著 である. 表面処理により䠅水化した粒子は粒子間凝集 力の減少により安定な密充てん構造を形成しやすいの でかく找トルクはか觉って大きくなると説明できる.

以上のように粉体の流動現象は粒子間の空壮きの存 在一一充てん構造と粒子間の相互作用が働く粒子の接 触状態の関係から考皇ねばならない。このような粉体 の動構造と流動性の対応を知るために次のような実験 をおこなった。

\section{3 粉体の動構造とその流動性}

一般に集合系での粒子の接触状態に関する知見を得 るのは難しく, とくに流動状態に和ける粉体の動構造 を知ることはきわめて困難である。，一方，粉体粒子の 接触状態が直接関係する現象として熱や電気の伝導が あり，とくに電気抵抗は測定が容易なので金属粉体の 充てん過程の測定などに利用されている. しかし, 通 常の金属粉体は表面酸化膜の存在などにより接触抵抗 が大きく, 流動粉体のように粒子が軽く接触し, しか も離合集散の著しい状態での電気抵抗の測定には問題 がある、そこで黒鉛粉体を試料として振動状態での粉 体層の電気抵抗の振幅による变化を測定し粉体の動構 造を推定しようと試みた。黒鉛は $3000^{\circ} \mathrm{C} の$ 高温で黒 鉛化したコークス粉末を主として用いたので表面に他

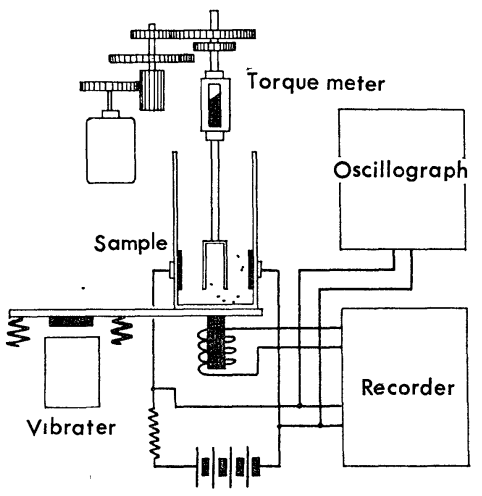

Fig. 4. Schematic diagram of the apparatus for measurement of structure and fluidity of powder bed in vibrating state.

物質の存在を考学る必要がなく，電導性も充分に大き いので都合が良い。

実験装置はFig. 4 のと和りで, バイブレータに取り 付けた試料容器は内径 $6 \mathrm{~cm}$ のアクリル樹脂円筒で内 部に電極が取り付けてある。 バイブレータの振動数は $60 \mathrm{~Hz}$ で, 入力電圧を一定速度で変えて振動強度（振 幅）を変える. 振幅は試料容器の下部にある検出器で 検出して記録計に入れ, 試料層の電気抵抗の変化子対 応できるようにした．粉体層の流動性は容器中に挿入 した回転粘度計のトルクにより測定する。

バイブレータに加える電圧を変化させながら，振幅， 試料層の電気抵抗和よび試料の流動性の変化過程をみ ると Fig. 5，6のよらになる。すなわち，粉体層の電 気抵抗は振幅の增加につれて Fig. 5 の曲線 $\mathrm{ABCD}$ の 上らに変化し, 加光る電圧の変化速度が一定であれば 増加, 減少のどちらの過程でも一致しょい再現性を示 している. 最初, 静止状態からしばらくの間は電気抵 抗は変わらないが $\mathrm{B}$ 点から急に増加し, 粉体層中の粒 子が動きはじめ接触状態が変わってきたことを示すが 粉体層の変化は肉眼的にはまた諗められない。さらに

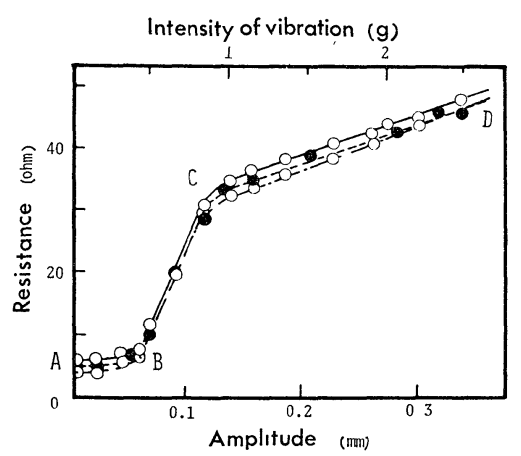

Fig. 5. Change of electric resistance with amplitude of vibration., $\bigcirc$, (-) : Amplitude increase, Amplitude decrease. 


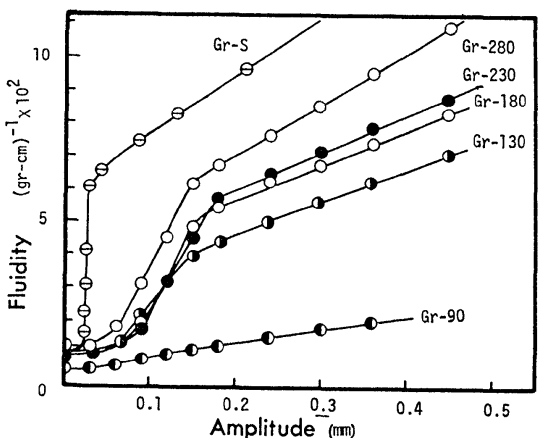

Fig. 6. Relation between amplitude and fluidity of powder beds.

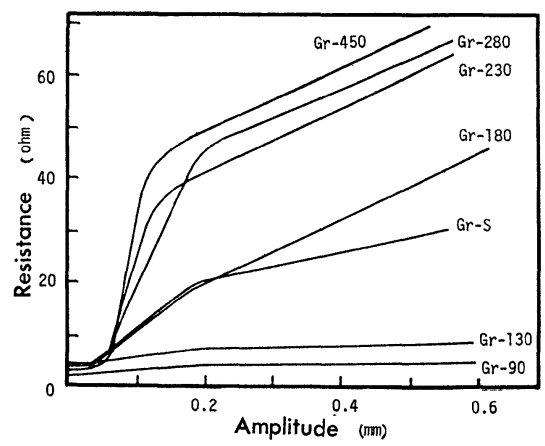

Fig. 7. Relation between amplitude and electric resistance of powder beds.

振幅が増加していくとC 点から抵抗変化が少なくなり こう配が小さくなる。この経過はFig. 7 のように試料 の粒度に関係なくすべて同じ傾向を示すが，電気抵抗 の変化量は粒度が大きいほど大きく，これらの曲線の $\mathrm{BC}$ 部のこう配は粒子の平均重量とほぼ対応するよう である。

粉体層中に挿入した回転粘度計のトルクは振動が強 くなるにつれて減少する。ここでは測定されたトルク の逆数 $(\mathrm{g} \cdot \mathrm{cm})^{-1}$ を試料粉体の流動度と定義し，その 振幅による変化をみるとFig. 6 のように電気抵抗の場 合と同様の傾向を示す.

粉体層の電気抵抗も流動性もとも飞構成粒子の接触 状態に関係するからその振幅による変化は粒子の同じ 挙動にもとづくものであろう. Fig. 6, 7 の $\mathrm{CD}$ の領 域江抬ける電気抵抗 $R_{x}$ 9変化と, 対応する流動度 $\phi$ の間には各試料についてFig. 8 のらな関係があり， (2)式が成立する。

$$
\phi=a \exp \left(-b \frac{R_{0}}{R_{x}}\right)
$$

ここで $R_{0}$ はこの実験に括ける試料の最も密な充て 几状態 $\mathrm{A}$ 点に和ける抵抗值である。粉体充て几層の電 気抵抗の解釈は簡単ではないが, 粒子相互の接触数と 接触強度が関係するから粒子間の相互作用の程度に比

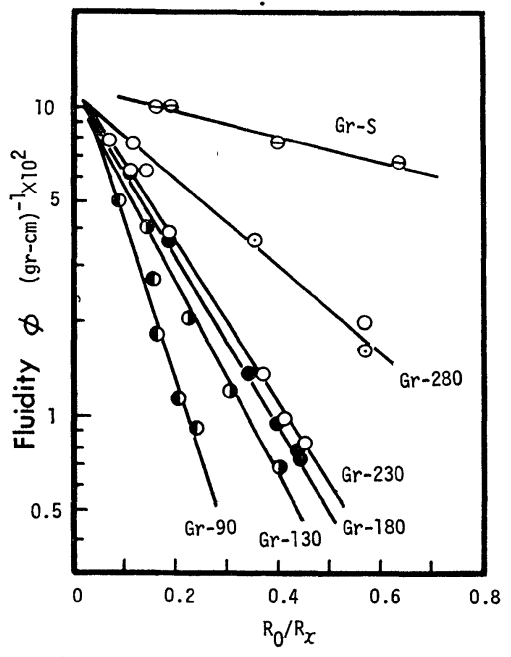

Fig. 8. Relation between $R_{0} / R_{x}$ and fluidity.

例していると考光てよからう。したがって $R_{0} / R_{x}$ は 振幅の変化にともなら粒子間相互作用の程度の変化で あり, 静止した最も安定な充てん状態の時に 1 , 完全 に粒子が分散した不連続状態では $R_{x}$ を無限大と考兄 てよいから 0 となるはずである。そして粒子が相互に 無接触であるとすればそのときの流動度中は試料に関 係なく装置の機械的な摩擦などによってきまる定数 $a$ となるであうう。Fig. 8 から得られた定数 $a ， b$ は Table II のと扮りで，aは試料関係なくほぼ一定 でありこのことと矛盾しない，また，Fig. 5 と示した ようにC 点付近で振動強度が重力加速度と対応するよ

Table II. Values of constant $a, b$.

\begin{tabular}{c|c|c}
\hline Sample & $a$ & $b$ \\
\hline Gr-90 & 13.5 & 5.13 \\
Gr-130 & 10.0 & 3.03 \\
Gr-180 & 12.0 & 2.63 \\
Gr-230 & 12.0 & 2.78 \\
Gr-280 & 11.0 & 1.45 \\
Gr-S & 12.0 & 0.43 \\
\hline
\end{tabular}

らになるから，CD 領域では粒子の運動はきわめて自 由でその平均的な接触構造は粒子相互の衝突数に支配 されると考えられる。したがってこの状態で粉体の流 動度は粒子が衝突するまでに動く距離や粒子の大きさ に関係し，振動層中の空げき体積が増すほど大きくな る. 粒子の接触構造の変わり方に対応する流動度変化 をあらわす定数 $b$ が粒度和よび粒子形状に対応してい ることは Table II のと拈りである.このように考え ると(2)式が熔融したガラス状物質の粘度と構成分子の 自由体積の関係を示す Doolittle の粘度式と同じ形で あることは興味がある。 
振幅が小さく加速度が $1 \boldsymbol{g}$ 以下の $\mathrm{BC}$ の領域では, 粒子が重力によって相互に接触しながら振動している であろう，振幅が減少していく場合にはこのままでよ り安定な充てん構造に移っていくから接触点数の増加 と接触圧力の增大が電気抵抗を減少させ同時に流動性 を低下させる。この過程では粒子が大きい注ど粒子間 の相互作用力は相対的に小さいから安定構造を形成し やすく， BC 部の傾きが粒子重量と関係することにな るのであろう。この過程で, 振幅の減少速度が大きく 充てん速度が速いと粒子が相互に干涉して安定な位置 がとれず，部分的に架橋構造を形成した空げきの大き い準安定構造となる。これはFig. 9 のようと振幅減少 速度を変克て電気抵抗变化を測定すればわかる。した がって強く振動させている粉体層を急清静止させると Fig. 9 の破線で示したよらに安定な密充てん構造とな らないから振動充てんによるカサ密度測定器では注意 を要する。

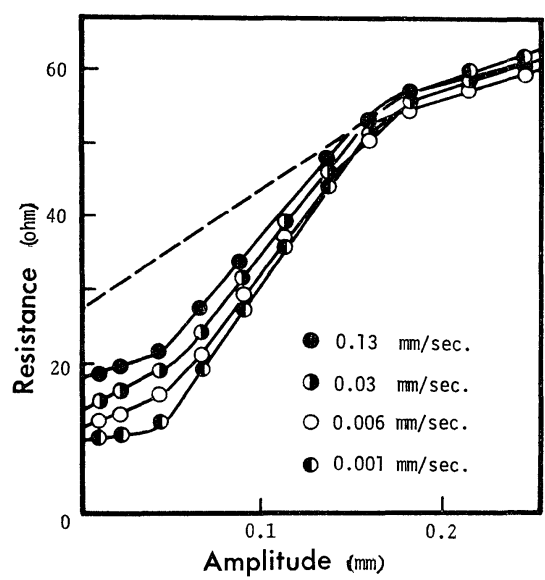

Fig. 9. Influence of decrease rate of amplitude for amplitude-resistance curve.

以上の上うに，振動粉体層の流動度は粒子の充てん 構造に関係する量（電気抵抗変化として）と粒子物性 に関する定数 $b 、$ 抢よび装置定数により与兄られるか ら，適当な振動条件を定めて測定すれば粉体の比流動 度を得ることができる。

な和，振動を加光たとき粉体層の動構造が均一と見 なせるかを確かめるために Fig. 10 (a)のような容器を 用いて黒鉛粉体の電気抵抗 $R$ の高さ $h$ 亿対する変化を いろいろの条件で測定した。結果は Fig. 10 (b)に例示 したように, 静止した容器に注入したときは層の上部 と底部は中央部より空げきが大きく，この傾向は粉体 層上部に圧力を加えて圧密しても残っている。しかし， 注入後, 振動を与えると上部はかなり充てえ構造が粗 であるが全体のほぼ3/4程は大体均一な構造と見なして もよいようである。したがって回転粘度計の円筒はな (a)

(b)

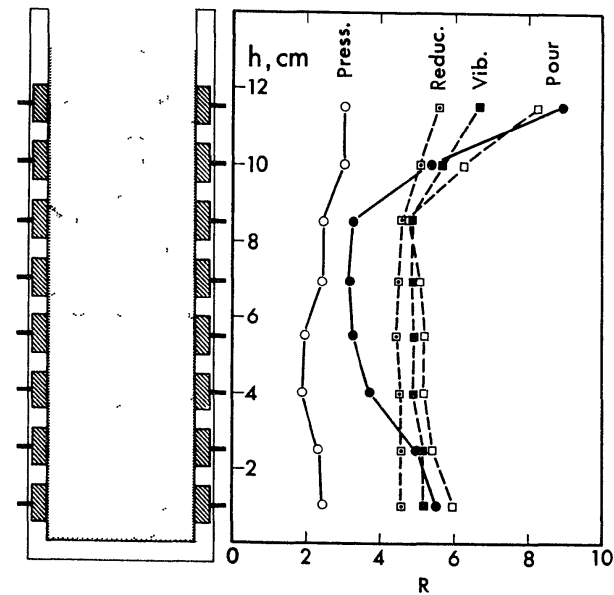

Fig. 10. (a) Apparatus. (b) Change of electric registance with hight of powder bed.

るべく粉体層中に深く挿入する方がよい.

4 流動粉体層における粒子物性と分離，偏析

粉体の流動性が関係するいろいろの現象を一種の拡 散過程と考兄て粒子の挙動を運動論的に解析する試及 は幾つか行なわれているが, 粒子間, とくに異種粒子 間の相互作用を考慮している例はない，前述のように 流動粉体中の粒子は当然粒子間相互作用力の影響を受 けて拈り, 粉体の混合, 偏析, 分離なども粒子特性之 の関連を考兄て論ずる必要がある。振動している粉体 層に対する他の粉体の拡散は微視的にはポテンシャル による粒子の移動現象であり，粒子間相互作用む当然 関係しているはずである。そこで物性や粒度の異なる 数種の粉体の組合せについて振動粉体層における粒子 の拡散過程を測定した。

Fig. 11 に示したように，径 $24 \mathrm{~mm}$ ，目開き $80 \mu$ の小形フルイに粗粉体を入れ，その上にさらに同じフ ルイを重礼でイフブレータに取り付け一定振幅で振動 させる．上のフルイ網上にフルイ目を充分に通れる大 きさの微粉体を少量入れるとフルイ目和よび粗粉体層

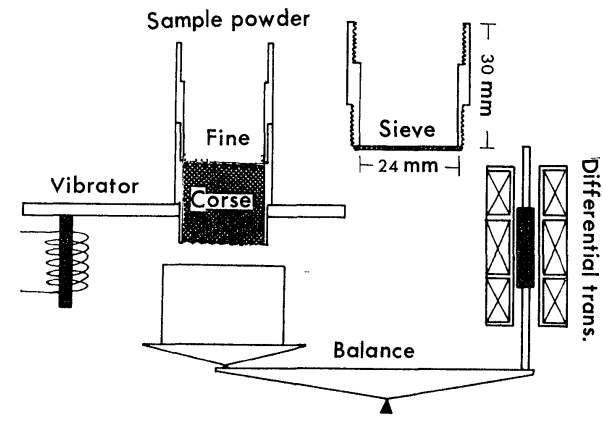

Fig. 11. Apparatus for measurement of percolation of fine powder through packed bed. 
を通過し，下のてんびんの受皿に落下する，通過重量 は差動トランスで検出し記録する。測定中の振幅変化 は 2 〜\%程度である。

振動粉体層を通過した微粉体量の時間的増加を振幅 をパラメータとして示すと一般に Fig. 12 のようとな る. 図中の数字は振幅 $(\mathrm{mm})$ で, ある程度以下の振 幅になると急に通過速度が遅くなる。

このような振動強度による粒子の通過速度の変化は 個々の粒子の運動エネルギの変化によるはずである.

通過量〜時間曲線のこう配が最大となる時間を微粉体 試料の振動粉体に対する平均透過時間 $t_{R}$ とし, その 逆数 $1 / t_{R}$ すなわち平均通過速度と振幅による微粒子 の平均的な運動エネルギの関係をみると Fig. 13 のよ らになり(3)式が成立する。

$$
\frac{1}{t_{R}}=K \cdot e^{\frac{\alpha}{2} M v^{2}}
$$

ここでMは粒子の質量， $v$ は粒子の平均速度， $K$ 特 よびはは定数である.

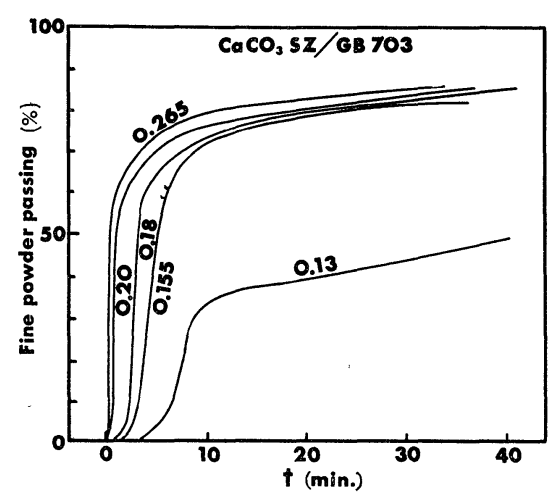

Fig. 12. Percolation curves of $\mathrm{CaCO}_{3}-\mathrm{SZ}$ through a packed bed of GB703. Number along the lines are amplitude ( $\mathrm{mm})$.

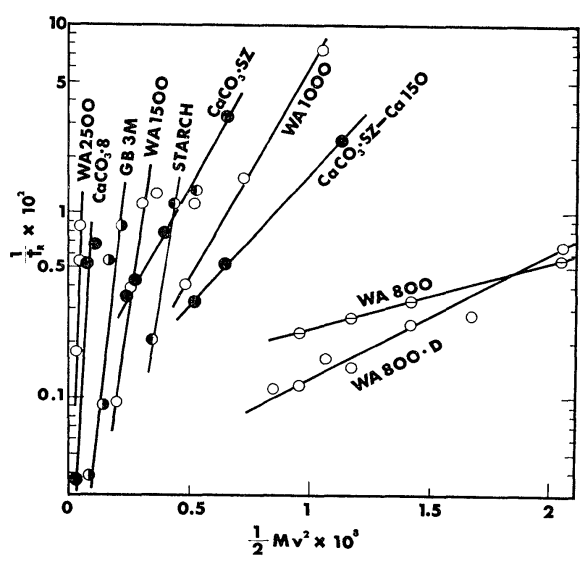

Fig. 13. Relation between $1 / 2 M v^{2}$ and percolation velocity of various powder through a packed bed of GB 703 .

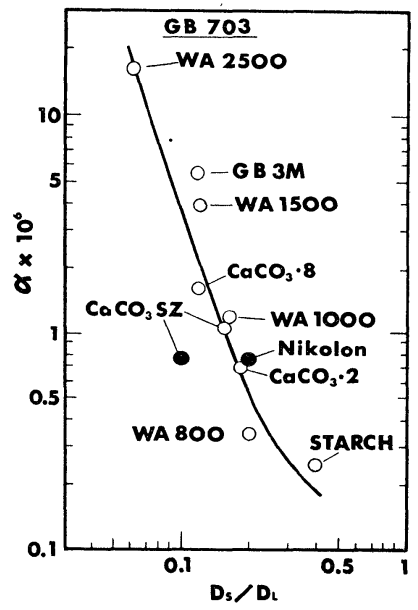

Fig. 14. Relation between $D_{\mathcal{S}} / D_{L}$ and $\alpha$.

“Fig. 13 亿扔いて，各直線のこう配 $\alpha$ は粒子の運動 エネルギの変化によって振動粉体層の通過しやすさが どう変わるかを示している。 このような粗粉体層に対 する微粉体の通過性には大小粒子の粒径比が関係する はずであるが，GB703 に対する種々の粒度の微粉体 の $\propto$ 之 $\mathrm{D}_{S} / D_{L}$ の関係は Fig. 14 のように相関性が認 められる， $D_{S} ， D_{L}$ は乞れ艺机微粉体招よび粗粉体の 粒子径である。

粗粉体と微粉体の物質の相違もかなり影響する。た と兊ば，親水性表面をもつ $\mathrm{CaCO}_{3}-\mathrm{SZ}$ ととれに表面 処理を抢こなって疎水性にした $\mathrm{CaCO}_{3}-\mathrm{SZP}$ の種々の 粗粉体に対する通過曲線は Fig. 15 のようになる。表 面が親水性の粗粉体 $\mathrm{GB}$ 之 $\mathrm{CaCO}_{3}$ 層では表面処理を した SZP の方が通過速度が大きいが，疎水性表面の 黒鉛層では逆に通過しにくくなり粒子間相互作用が増 したことを示している。このような結果から，微粒子 の拡散過程に括いて粒子間の相互作用力が影響し，親 水性表面の粒子間，疎水性表面の粒子間がそれぞれ付 着性が強いことがわかる。

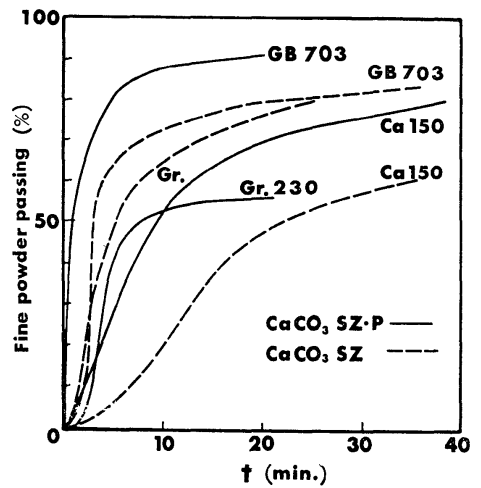

Fig. 15. Influence of surface treatment of percolating particles for percolating property. 
以上のような振動している粗粉体層に対する微粒子 の通過性一一拡散性に対して, (1)粗粒子との弾性衝突, (2)粗粒子表面への付着と脱離，(3)微粒子相互の凝集, 分散などの効果を考光ねばなららない。この実験では粗 粒子は充分に大きいので相互の凝集性を無視したが，

一般には当然考慮に入れるべきである。

通過量〜時間曲線の初期の急激な增加部分では通過 速度と振動強度の間に(3)式が成立し，そのこう配 $\alpha$ が $D_{S} / D_{L}$ に関係することは，この過程が主として粗粒 子表面とあまり相互作用せず間げきを通過する微粒 子によることを示している。この場合にも完全な弾性 衝突だけでなく粒子表面との付着や微粒子相互の凝集 ・分散の繰返しが通過に対する抗力として働いている ことは試料の種類や表面処理の有無, 湿度などが通過 性に影響していることから明らかである。

粗粒子表面に付着する微粒子は振動によって付着と 脱離を繰り返しているであるらが，その平均的な付着 量は周囲の粗粒子間げきに存在する微粒子量が多いほ ぞ增し，そして表面がひとと拈り付着粒子で扮拈われ るとそれ以上は付着できないだろう。また粗粒子表面 の付着量は振動強度によっても変化し, 振動が弱いほ ぞ付着量は増すであるう。したがって通過量〜時間曲 線後期の通過速度の遅い領域は粗粒子表面との付着, 脱離を繰り返しつつ通過する粒子群によるものと考兄 られる。この領域の粉体量を Fig. 16 のようにして定 めその割合を $R$ として，振動強度によるRの変化を各 試料について測定すると Fig. 17 のららになる。各試 料とも振動強度が減少すると急に $R$ の割合が增加しは じめる点がある．この点以上の振動強度では微粒子の 運動エネルギが粗粒子表面との付着力より大きくな り，粒子表面から脱離するとすれば，このときの運動 エネルギは大小粒子間の付着力に等しいはずである.

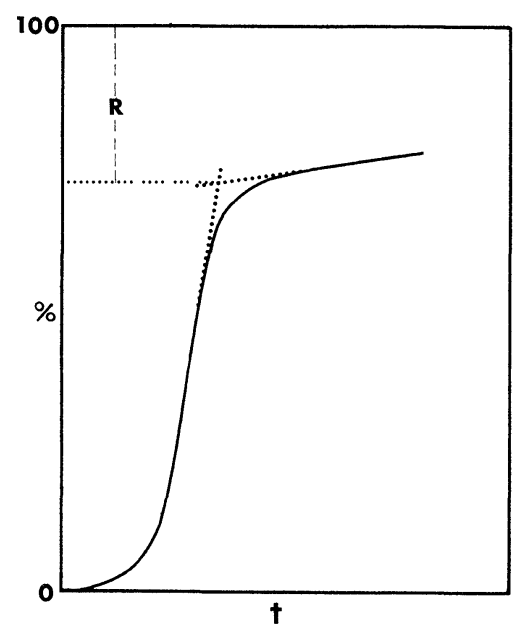

Fig. 16. Determination of residual value $R$.

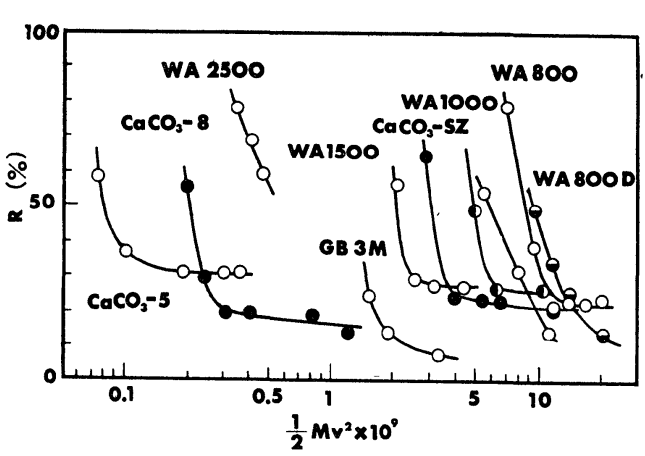

F1g. 17. Relation between $1 / 2 M \nabla^{2}$ and $R \%$ of various powder through a packed bed of GB 703 .

Table III. Adhesion force $f$ of various powder.

$\left(\mathrm{g} \mathrm{cm}^{2} \mathrm{sec}^{-2}\right.$ )

\begin{tabular}{|c|c|c|}
\hline \multirow{2}{*}{ Fine powder } & \multicolumn{2}{|c|}{ Coarse powder } \\
\hline & GB 703 & $\mathrm{Ca} 150$ \\
\hline WA-800 & $10 \times 10^{-9}$ & $20 \times 10^{-9}$ \\
\hline WA-1000 & $6 \times 10^{-9}$ & $7.5 \times 10^{-9}$ \\
\hline WA-1500 & $2.5 \times 10^{-9}$ & - \\
\hline $\mathrm{CaCO}_{3}-\mathrm{SZ}$ & $3.5 \times 10^{-9}$ & $15 \times 10^{-9}$ \\
\hline $\mathrm{CaCO}_{3}-\mathrm{SZP}$ & $1.5 \times 10^{-9}$ & - \\
\hline $\mathrm{CaCO}_{3}-5$ & $0.1 \times 10^{-9}$ & \\
\hline $\mathrm{CaCO}_{3}-8$ & $0.3 \times 10^{-9}$ & \\
\hline $\mathrm{CaCO}_{3}-20$ & $3.4 \times 10^{-9}$ & - \\
\hline GB-3M & $16 \times 10^{-8}$ & - \\
\hline STARCH & $50 \times 10^{-9}$ & $\longrightarrow$ \\
\hline
\end{tabular}

Fig. 17 の の急増点の振動強度から求めたガラス 球 牰よび石灰石粗粒子に対する各試料の付着力を Table III に示した. 同種の粉体では付着力は粒度の関数の ようである。

このように試料によって通過特性が変わることが偏 析であるが，これによって粒子特性の異なる 2 種以上 の混合粉体の分離ができるはずである．Fig. 18 は $\alpha$ $\mathrm{Al}_{2} \mathrm{O}_{3}$ （角价った粒子）とデンプン（丸及状粒子）の 等量混合物を $\mathrm{GB}$ 層中に通し，一定時間ごとに採取 した通過粉体の顕微鏡写真で粒子の形状が違らからそ の割合が変化する様子がよくわかる，各時間ごとに 採取した通過粉体の混合比の時間的変化は Fig. 19 の

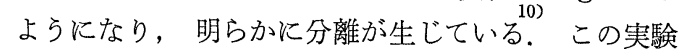
の場合，振動層厚さは $2 \mathrm{~cm}$ であるが，これを何段か 重社ると一層よく分離されるであるう。また，この 方法は粉体材料の偏析のしやすさを判定する手段にな る. 

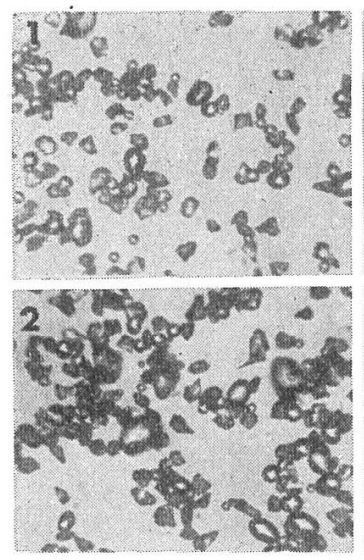

1. $100 \mathrm{sec}$., 2. $180 \mathrm{sec}$., 3. $240 \mathrm{sec}$, 4. $360 \mathrm{sec}$.

Fig. 18. Change of mixture ratio of WA-800/ STARCH system with the percolation time. (blocky: WA, round shape: STA$\mathrm{RCH})$.

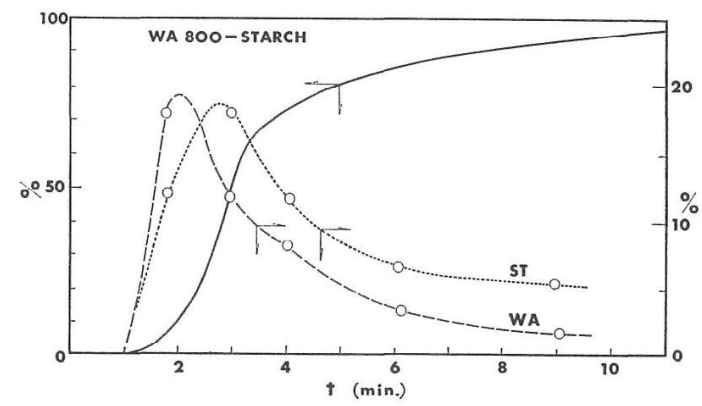

Fig. 19. Segregation of WA-800/STARCH system after the percolation through a packed bed of GB703.

\section{5 振動容器内の粒子循環流れと微粉体の挙動}

これまでは振動容器内で粉体粒子は一様に振動して いると仮定している。しかし，実際には振動層内の粒 子は決してアトランダムな運動をしているのではなく 容器形状によっていろいろの循環流孔を生じている. 容器形状を適当に選ぶと振動によって規則的な粒子循 環流れが生じるから年の中での微粉体の挙動と粉体物 性の関連をしらべてみだ。

Fig. 20 のよらな逆円すい容器の 2 次元モデル中に 粉体（この場合 GB）を入れて振動させる。振幅があ る程度大さくなると壁付近の粒子群が傾斜面に沿って 上昇しはじ，その空げきを埋めるために中央部の粒 子群が垂直に下降して循環流れを生じる。Fig. 20 で は着色粒子を加えてその様子がよくわかるようにして ある、粒子の拡散が㘯るので次第に全体に着色粒子が 広がるが，ちょうど目のよらにいつまでも混りあおな い部分ができている。この循環流れの速度は振幅が大 きいほど大きく，傾斜面に沿った上昇速度の方が中央 部の下降速度より大きい。着色粒子の移動速度をFig.
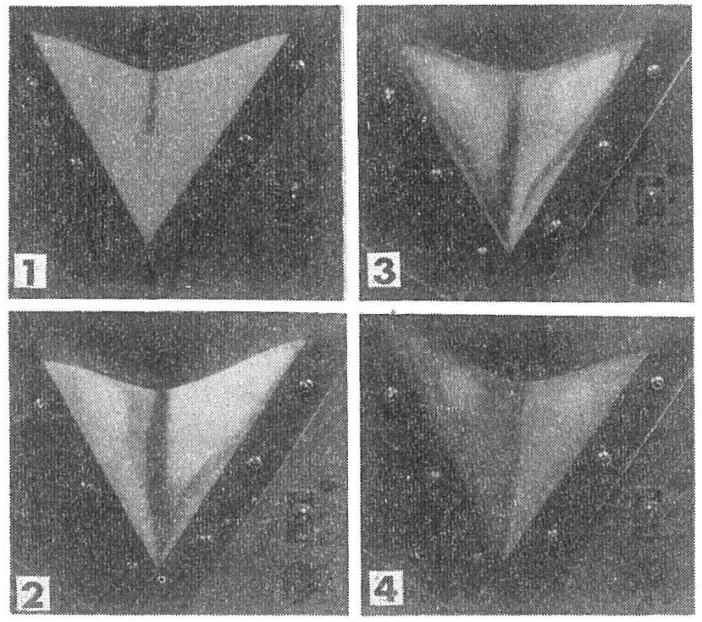

Fig. 20. Flow pattern of powder in conical container in vibrating state (two dimensional model).

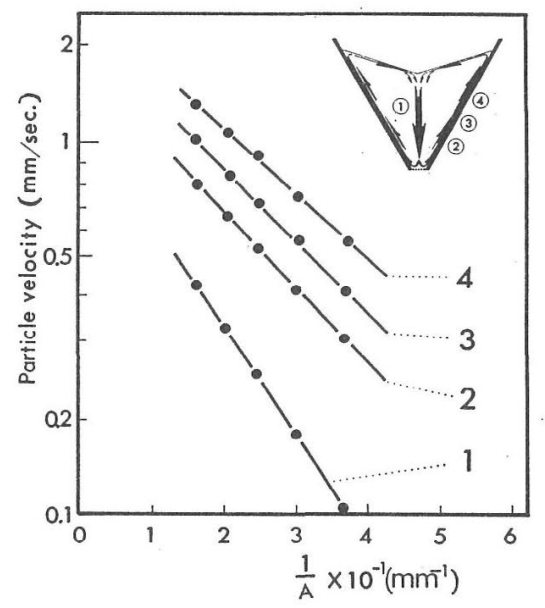

Fig. 21. Relation between amplitude $A$ and particle velocity in conical container.

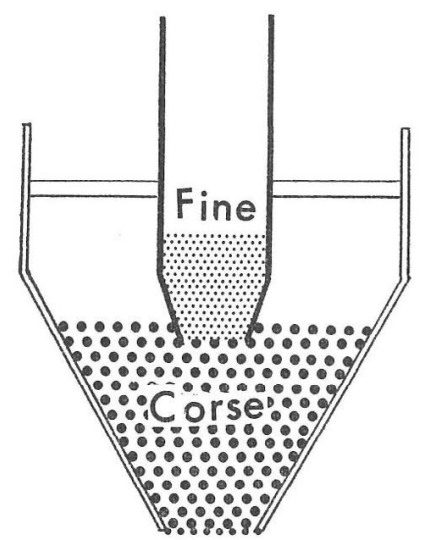

Fig. 22. Schematic diagram of container.

21のよらに容器の各処に括いて測定し，その振幅之の 関係をしらべると振幅の逆数 $1 / A$ と移動速度 $v$ 間 
に指数関数的関係が認好られ。この循環粒子流に微 粒子を拡散させて前述のような振動層中の通過速度の 測定を特こならためにFig. 11 の振動容器をFig. 22 の よらな円すい形のフルイに变えて同様の実験を和こな った。

4 節の実験では上部フルイに一定量の微粉体を入れ その全量が通過する過程を湘定したが，この実験では 上部フルイにつぎつぎと微粉体を追加して，定常状態 での通過速度と振幅の関係を検討した。Fig.23 GB 705 層に対与るデンプンの通過速度の振幅による变化 を示し，(a)は重量增加，(b)は振幅である．領域Aは振 幅 $0.17 \mathrm{~mm}$ で通過速度 $0.35 \mathrm{mg} / \mathrm{sec}$. B では 0.22 $\mathrm{mm}$ で $1.67 \mathrm{mg} / \mathrm{sec}$, Cでは $0.19 \mathrm{~mm}$ で $0.75 \mathrm{mg} /$ sec である。図から明らかなように振幅変化に詨する 応答速度はきわるて速い，振幅を一定にして和けば通 過速度の精度はかなり高く，たと光ば $1 \mathrm{mg} / \mathrm{sec}$ 程度 でかなり長時間の微量供給装置として利用できる。

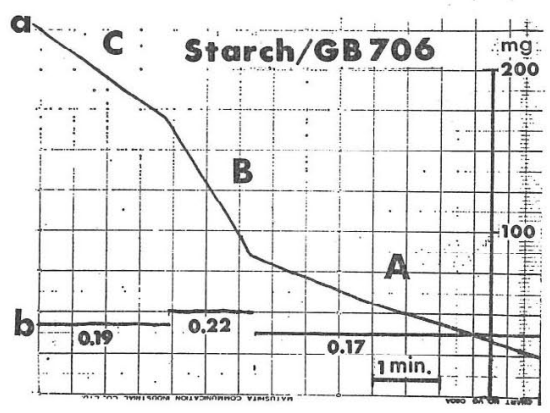

Fig. 23. Relation between amplitude and percolation velocity of STARCH through a bed of GB706.

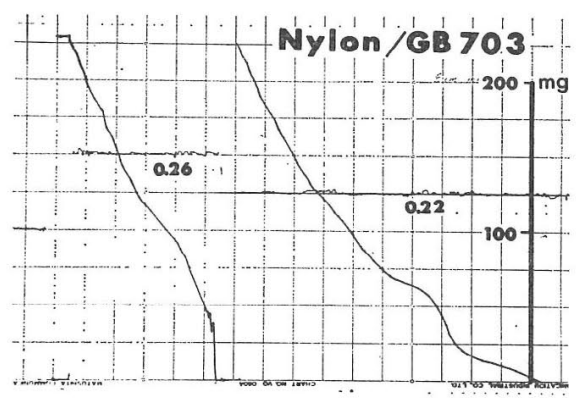

Fig. 24. Relation between amplitude and percolation velocity of Nikolon through a bed of GB703.

しかし, 微粉体と粗粉体の組合せによっては一定振 幅でも通過速度は一定せず，振幅の変化にる刘応しな い. Fig. 24 はその例でナイロン粉末をガラス球層に 通した場合である。乙かし，ナイロン〜黒鉛粉系では かなり通過性がよくなり，ナイロン〜ナイロン粗粒子 系ではきわめてよい結果が得られる。これは疎水性表
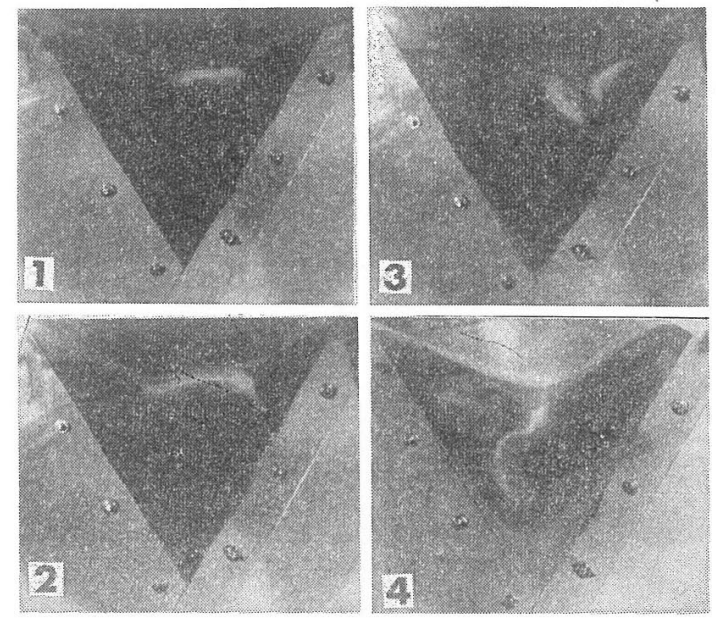

Fig. 25. Flow pattern of $\mathrm{CaCO}_{3}$ fine powder in Graphite coarse powder bed in vibrating state.

面粒子と親水性粒子のよらに表面特性の変わった組合 也でほ粗粉体愿への微粒子の桩散が悪く，微粉体の淡 集を生じて流動が不規則になるためで，この様子を二 次元容器によって示すと, Fig. 25 のように循環流れ が乱流となっている椂子がよくわかる。この図は Ca$\mathrm{CO}_{3}$ 之黒鉛粗粉体の系である。

流動が振幅の変化によく刘応する種々の粉体系につ いて振幅の逆数と通墖速度の関係を片効数でプロット するとFig. 26 のよう火直線となる。このことは，振 動容器に供給された微粒子が粗粉体振動層中の循環流 れにのって振動層を通過し，下のメッシュから排出さ れることによると思われるが，粉体の組合せがこの現 象に大きく影響することを考えると，Fig. 26 の関係 には粒子特性の効果が含まれていることが期待される. そこで幾つかの系について粉体の組合せ, 粒度, 粒子 表面特性などの影響をしらべた。

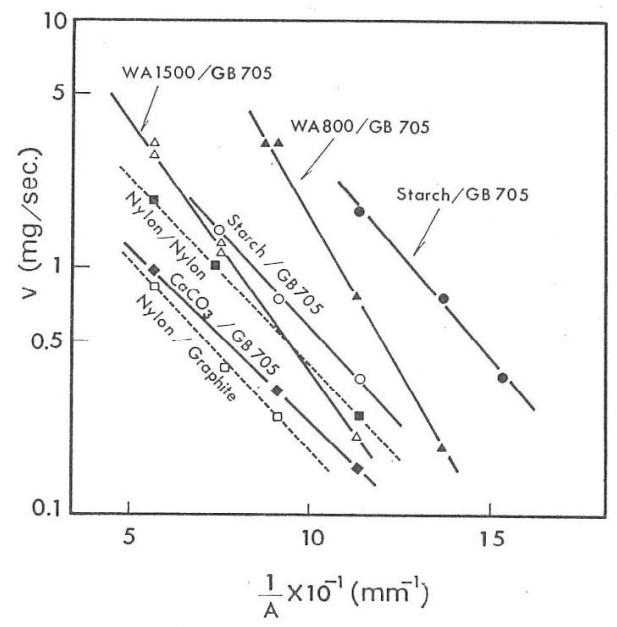

Fig. 26. Relation between amplitude of container and percolation velocity of various powder. 


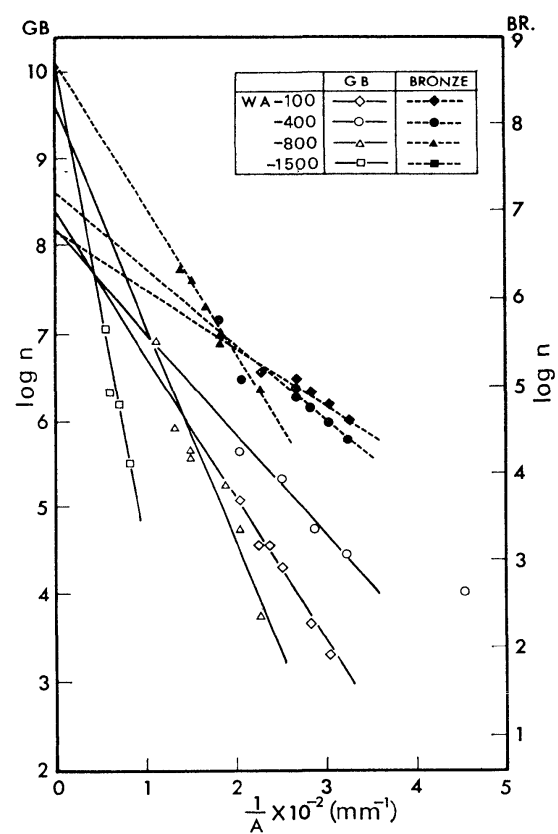

Fig. 27. Relation between amplitude of container and percolation velocity (number base) of various sized $\alpha$-Alumina.

Fig. 27 は種々の粒度の $\alpha-\mathrm{Al}_{2} \mathrm{O}_{3}$ のガラス球特よ び球形砲金粉体の振動層に対する通過速度と振幅の逆 数 $1 / A$ の関係で, 通過速度は単位時間に通過した粒 子数nで示してある，振幅が大きい方が $n$ が大きくな るが，傾向として砲金粉の方が通過しやすく，通過粉 体の粒度によって切片抒よびこう配が変わる，振幅が あまり大きくない部分では粒度の小さい力が $n$ が少な く通過しにくいのは粒子間凝集力の効果によると考兄 られる。しかし WA-100 が逆にnが少なくなるのは 粗粒子循環流の粒子間げきに入るには粒度が大きすぎ

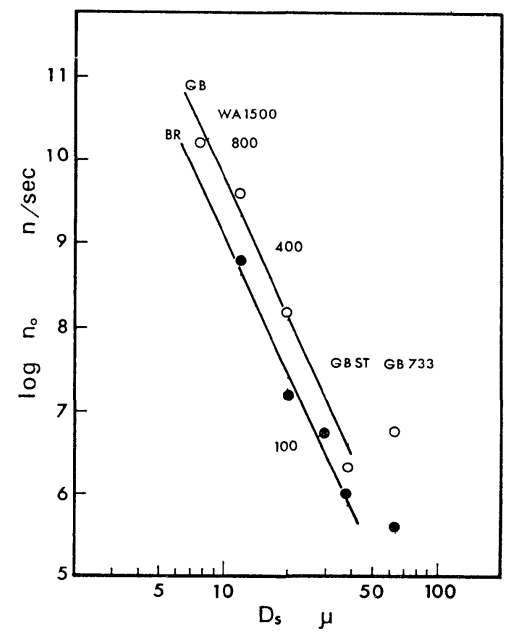

Fig. 28. Effect of particle size on intercept of $1 / A-\log n$ plots.

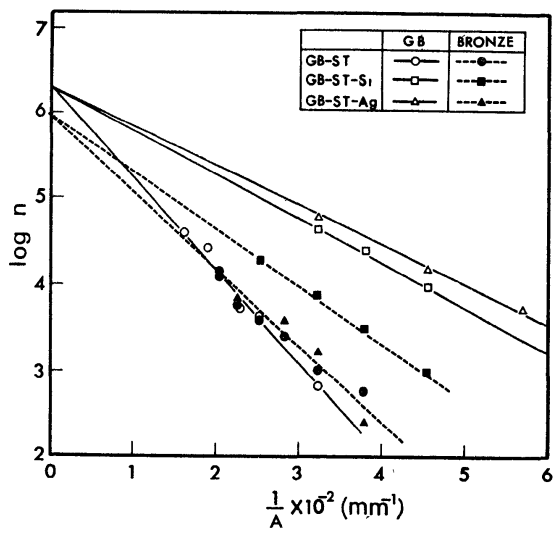

Fig. 29. Effect of surface treatment on the relation of $1 / A$ and $\log n$.

るためであろう。振動強度が無限大，すなわら $1 / A$ が 0 のときの通過速度 $n_{0}$ は Fig. 28 のように粒度が小 さい注ど大きい，粒度があまり大きいと逆になるのは やはり粗粒子との粒径比できなる限界径の存在を示し ている.

Fig. 29 は粒子の表面特性による通過特性の変化で, 同じガラス球粒子で表面にンリコンコーチングをして 蹯水性にしたもの, 銀ニーチングを施したものと末処 理の試料の比較である．ガラス粗粉体層に対しては表 面処理の效果が大きく，表面が䠅水化されたため的 ラスの粒子間の付着・凝集力が減少し通過しやすい. したがって偏析しやすいことを示している。砲金粉体 層については銀コーチング試料は無処理試料の通過性 とあまり変わらず同種の表面の相互作用があることを 示している. シリコン処理試料はやはり通過しやすい. また，どちらの粉体層に执いても切片は表面処理の有 無に関係なく一致し，これが主として粒度の効果であ ることがわかる。しかしこう配は粒度と表面特性の両 方に関係しているようである。

このよらな振動粉体層中の微粉体の通過速度に関係 する因子を整理すると, 微粒子相互の凝集力 $f_{p}$ と微 粒子〜粗粒子間の付着力, 付着·凝集力に対する反力 として作用する粒子の運動量に関係する粒子重量 $W_{p}$ がある．粗粒子間の凝集力は無視できるとする．この よらな粒子間相互作用は実験結果からわかるように粒 子の表面の性質に依存しているし，またとの作用機構 は大気中では粒子表面吸着水膜の効果が主要なものと

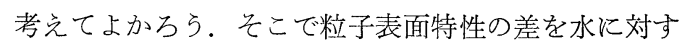
るこれら粒子の妨やすさ一接触角で示し，大小粒 子の表面の水之の接触角 $\theta_{L}, \theta_{S}$ の比

$$
R_{\theta}=\frac{\theta_{S}}{\theta_{L}}
$$

によって表面特性の類似度をあらわすことにした，粒 子の接触角は Bartell の方法によって測定した． $R_{\theta}=$ 
1 のとき大小粒子の表面親水性が等しく, 大きくなる ほど表面の性質が異なり粒子間の相互作用力が小さく

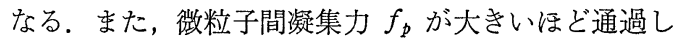
にくく, 粒子重量 $W_{p}$ は粒子の運動量に関係して大き いほど通過しやすい。そこで，これらをあわせて仮り に $\left(f_{p} / W_{p}\right) / R_{\theta}$ を粒子間力の総合評洒指数として用 いる。 $f_{p}$ は一面せん断試験により測定した。

$\left(f_{p} / W_{p}\right) / R_{\theta}$ と, 振動強度〜通過速度直線のこう 配 $P$ の関係は Fig. 30 のように相関性があり，粒子間 親和性が大きい法ど，すなわち $R_{\theta}$ が小さいほど $P$ ず 大きく，また $f_{p}$ が小さいほど通過性が悪くなる。乙 たがって粒子表面の性質が違う粉体ほど混合粉体の場 合，偏析が生じやすいことがよくあらわれている。

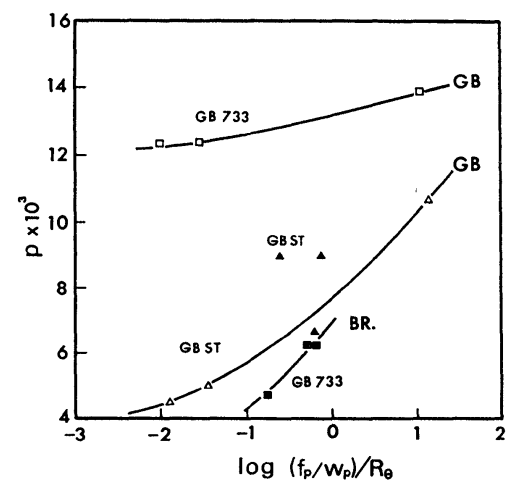

Fig. 30. Relation between $\log \left(f_{p} / W_{p}\right) / R_{\theta}$ and slope of $1 / A-\log n$ plots.

\section{6 あ と がき}

以上，著者らが続けている振動粉体に括ける流動現 象と粒子特性の関係をまとめて述べた。すでに述べた ように振動層に和ける諸現象がただちに粉体の流動性 の指標として役立つわけではない，しかし，一定条件 で “動いている”粉体中での粒子の挙動と, 粒子の基 礎的性質である粒度や粒子表面の性質などとの関係を
知ることは粉体の動特性の基礎的研究のアプローチの 一つであるには違いない。ここに述べた時点では振動 現象に括けるきわめて重要な因子である振動数の効果 に関しては全く研究していないが, 今後, その点も確 かめていきたいと思う。

（昭和48年10月 5 日 第11回粉体に関する討論会にて講演）

\section{参 考 文 献}

1）三輪茂雄, “粉粒体工学”, p.185 (1972) 朝倉書店

2）古川淳二, 大前 協, 工化誌, 50, 82 (1958); Hetzler, R., and M.C. Williams, I \& EC, Fundamental, 8, 668 (1969).

3）森 芳郎, 神保元二, 山崎昌男, 化学工学, 28, 204 （1964）；杉本益規，遠藤一夫，田中達夫，化学工学, 30, 427 (1966); 杉本益規, 第 9 回粉体に関する討論会講演 要旨集, p.59 (1971); 杉本益規, 山本健市, 第10回粉 体に関する討論会講演要旨集, p.19 (1972).

4）たとえば, McDougall, I. R., et al., Trans. Inst. Chem. Eng., 47, 73 (1969) ; Brown, R.L., and J. C. Richards, "Principles of Powder Mechanics", p. 135 (1970) Pergamon Press

5) 西野 操, 荒川正文, 材料, 19, 560 (1970); 荒川正文, 粉体工学研究会誌, 9, 476 (1972).

6) 荒川正文, 西野 操, 水渡英二, 材料, 17，545 (1968).

7) Harwood, C.F., and N. Pilpel, Chem. Proc. Eng., 49, 92 (1968).

8) 荒川正文, 西野 操, 材料, 20, 776 (1971).

9) 荒川正文, 西野 操, 材料, 21，562 (1972).

10）荒川正文, 西野 操, 日本化学会第26春季年会講演要旨 集, I, p. 562 (1972).

11) Takahashi, H., A. Suzuki, and T. Tanaka, Powder Tech., 2, 65 (1968).

12）荒川正文, 西野 操, 日本化学会第 28 春季年会講演要旨 集, I, p.36 (1973).

13) Bartell, F.E., and H. J. Osterhof, Ind. Eng. Chem., 19, 1277 (1927). 